\title{
The biogeochemical characteristics of phosphorus in coastal sediments under high salinity and dredging conditions
}

\author{
Guoqiang Zhao ${ }^{\text {a, b }}$, Yanqing Sheng a, ${ }^{\text {, }}$, Ming Jiang ${ }^{\text {a, b }}$, Haoyuan Zhou ${ }^{\text {a, b }}$, Huichao Zhang ${ }^{c}$ \\ ${ }^{a}$ Research Center for Coastal Environment Engineering Technology of Shandong Province, Yantai Institute of Coastal Zone Research, Chinese Academy of \\ Sciences, Yantai, China \\ ${ }^{\mathrm{b}}$ University of Chinese Academy of Sciences, Beijing, China \\ c School of Civil Engineering, Yantai University, Yantai, China
}

\section{H I G H L I G H T S}

- River and coastal sediments were analyzed to characterize P pools and forms.

- High salinity kept the OP at a low content and promoted to increase $\mathrm{Fe} /$ Al-P content in acid river sediments.

- Sediment dredging regenerated $P$ from Ca-P and OP, and increased the potential activity of OP and IP.

- Seawater could induce removal of the $\mathrm{Fe} / \mathrm{Al}-\mathrm{P}$ and OP from offshore sediment.

\section{A R T I C L E I N F O}

\section{Article history:}

Received 4 June 2018

Received in revised form

23 September 2018

Accepted 3 October 2018

Available online 16 October 2018

\section{Keywords:}

Phosphorus

Coastal sediments

Salinity

Sediment dredging

Bohai sea
G R A P H I C A L A B S T R A C T

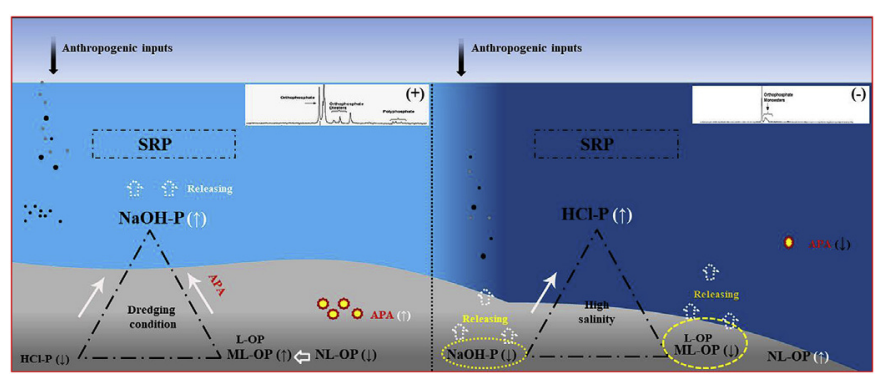

\begin{abstract}
A B S T R A C T
The geochemistry of phosphorus (P) can usually be related to prevailing environmental conditions. To investigate sedimentary P cycling mechanism and biogeochemical characteristics under high salinity and dredging conditions in polluted coastal sediments, thirty-three surface sediment samples were collected from the Jiehe River $(\mathrm{JH})$, Jiaolai River $(\mathrm{JL})$ and their estuarine and offshore areas in the Bohai Sea. Analyses included the Standards, Measurements and Testing method (SMT), Ivanoff organic P (OP) fractionation, and nuclear magnetic resonance $\left({ }^{31} \mathrm{P}-\mathrm{NMR}\right)$ of soluble $\mathrm{P}$ and indicated that $\mathrm{HCl}-\mathrm{P}$ was the dominant fraction in sediments under high salinity stress. However, under dredging conditions in freshwater river sediments, NaOH-P was the dominant fraction. The potential activity of the OP fraction was reactive in freshwater river sediments, while it was unreactive under high salinity conditions.

$\mathrm{NaOH}-\mathrm{P}$ and $\mathrm{HCl}-\mathrm{P}$ were found to be mainly derived from anthropogenic inputs, whereas both in-situ biological and anthropogenic inputs were important sources of the OP fractions. High salinity had the potential to increase $\mathrm{NaOH}-\mathrm{P}$ content in acidic river sediments, resulting in the OP being relatively stable with a low risk level. Sediment dredging potentially increased the regeneration of $\mathrm{P}$ from $\mathrm{HCl}-\mathrm{P}$ and OP and increased the potential activity of OP and IP. Seawater was found to induce removal of the NaOH-P and OP from offshore sediments, resulting in the regeneration of the remaining $\mathrm{P}$ at a low level.
\end{abstract}

๑) 2018 Elsevier Ltd. All rights reserved.

\footnotetext{
* Corresponding author.

E-mail address: yqsheng@yic.ac.cn (Y. Sheng).
}

\section{Introduction}

Phosphorus (P) plays a vital role in organism growth in coastal ecosystems, while excess $P$ is a crucial factor in eutrophication 
(Meng et al., 2015; Schindler, 1977). Sediment has been identified as not only a major sink of external inputs but also a major source of internal P into the overlying water column (Zhou et al., 2001). Although anthropogenic inputs of $P$ to coastal environments have gradually been increasingly controlled over the past several years, water quality has not improved due to the continued release of internal $P$ accumulated in sediments of aquatic ecosystems which has become an important source of P (Sondergaard et al., 2003; Zhou et al., 2001).

Previous studies have illustrated that the $\mathrm{pH}$, dissolved oxygen (DO), oxidation reduction potential (ORP) in the overlying water can significantly influence the adsorption and desorption of $\mathrm{P}$ in surface sediments (Chen et al., 2010; Huang et al., 2005; Li et al., 2016). Salinity of the overlying water has also been reported to result in rapid release of $P$ from sediments, especially the Fe-P release because the salinity of the overlying water had a significantly inverse correlation with the Fe-P in the sediment (Jordan et al., 2008). Increased salinity of the overlying water column can also inhibit the regeneration of reactive $P$ from OP due to suppression of alkaline phosphatase activity and phytoplankton (containing abundant OP) growth (Labry et al., 2016). Previous studies have demonstrated that there was an increase in the amount of polyphosphates from sediments due to increased salinity which induced plasmolysis of bacteria, resulting in the release of stored polyphosphates (Gardolinski et al., 2004). Sediment dredging is an effective and widely used technique in the remediation of heavily polluted sediments (Yu et al., 2016). However, previous studies have shown that any disturbance and/or environmental alterations can pose a potential risk of a $\mathrm{P}$ increase in the water column. Sediment disturbance, including dredging, can accelerate the release of readily available $P$ which was previously bound within the sediment (Wang et al., 2011). However, dredging can improve the redox conditions in surface sediments by facilitating the formation of Fe oxides (hydroxides) (Zhong et al., 2009), which then allows $\mathrm{PO}_{4}^{3-}$ to become bound with the Fe oxides (hydroxides) to increase the Fe-P in sediments (Chen et al., 2018). In addition, disturbance of subsurface sediments can result in organic matter (including OP) in the deeper sediment being exposed to oxygen and light, which in-turn can induce degradation of OP (Bertrand et al., 2012). However, the effect of abnormally high salinity on the sedimentary biogeochemical characteristics of $\mathrm{P}$ and the mechanism of $\mathrm{P}$ regeneration in post-dredging sediments with a high $\mathrm{P}$ content have rarely been investigated.

There are many classical P fraction analysis methods, such as the Standards, Measurements and Testing Program (SMT), the Ivanoff organic P (OP) sequential extraction and ${ }^{31} \mathrm{P}-\mathrm{NMR}$ (Cade-Menun and Preston, 1996; Ivanoff et al., 1998; Ruban et al., 2001). However, each method has its limitations. For example, the SMT protocol can divide sedimentary $\mathrm{P}$ into $\mathrm{NaOH}$ extractable inorganic $\mathrm{P}$ ( $\mathrm{NaOH}-\mathrm{P}, \mathrm{P}$ bound to $\mathrm{Al}, \mathrm{Fe}$ and $\mathrm{Mn}$ oxides and hydroxides), $\mathrm{HCl}$ soluble $\mathrm{P}$ ( $\mathrm{HCl}-\mathrm{P}, \mathrm{P}$ associated with $\mathrm{Ca})$, organic $\mathrm{P}(\mathrm{OP})$, inorganic $\mathrm{P}$ (IP) and total P (TP) (Ruban et al., 2001). However, this protocol fails to provide any information on the potential activity and structure of the OP (Zhu et al., 2013a). Some IP may be strongly immobilized by association with minerals during diagenesis, which leads to incomplete extraction of IP by $\mathrm{HCl}$ in the SMT protocol. The OP determined by the SMT protocol also has the potential to be overestimated (Zhu et al., 2018). Fortunately, the OP potential activity can be determined using the OP fractionation method by dividing OP into readily labile, moderately labile and non-labile OP in the potential activity sequence order according the Ivanoff scheme (Ivanoff et al., 1998). However, the structure of the OP cannot be determined and the residual OP (ignition treatment) is also overestimated (Turner et al., 2005). The $1 \mathrm{D}^{31} \mathrm{P}-\mathrm{NMR}$ and/or $2 \mathrm{D}{ }^{1} \mathrm{H}-{ }^{31} \mathrm{P}-$ NMR correlation spectroscopy are advanced and powerful tools that can analyze OP at the structural and molecular level. Many OP compounds, such as myo-inositol, hexakisphosphate, glyphosate, DNA and choline phosphate have been detected in sediment samples utilizing these methods (Vestergren et al., 2012). The drawback of this NMR method is that many OP compounds are easily degraded in the simple $\mathrm{NaOH}-\mathrm{EDTA}$ extraction in addition to poor overall recoveries (Cade-Menun and Liu, 2014). Thus, given the above, it is necessary to use multiple complimentary methods to comprehensively investigate the biogeochemical characteristics of coastal sedimentary P.

The Jiehe River $(\mathrm{JH})$ and the Jiaolai River $(\mathrm{JL})$ are coastal polluted rivers along the Laizhou Bay in China. The JH is a freshwater river heavily polluted with $P$ and heavy metals (Tables 2 and S5). The JL is a high salinity river due to inputs from the many salt fields on both sides of the river. The objectives of this study were to analyze $P$ pools and forms using a combination of methods (SMT, Ivanoff fractionation and ${ }^{31} \mathrm{P}-\mathrm{NMR}$ ) and relate these to other geochemical parameters to gain insight into the potential factors influencing $\mathrm{P}$ cycling in the sediments.

\section{Methods and materials}

\subsection{Sample collection}

To study the biogeochemical characteristic of $\mathrm{P}$ in coastal sediments under high salinity and dredging conditions, thirty-three surface sediment $(0-10 \mathrm{~cm})$ samples were collected from the $\mathrm{JH}$ (freshwater with heavy pollution), the JL (high salinity) and the corresponding offshore areas ( $\mathrm{J}$ and L marked respectively) in the Bohai Sea (Fig. S1). The sediments were collected with a Van Veen grab in August, 2017 and samples immediately (in $~ 1 \mathrm{~min}$ ) stored in plastic zip lock bags (flushed with nitrogen prior to use), kept cold with ice packs and transported to the laboratory within $12 \mathrm{~h}$ where they were frozen in a $-20^{\circ} \mathrm{C}$ refrigerator until analysis. All sediments were homogenized prior to analysis.

\subsection{Sample analysis}

The physical and chemical parameters in the surface water ( 5-10 cm below the surface) were measured in situ using a YSI instrument (YSI Professional Plus, YSI Incorporated, USA). The total organic carbon (TOC) and total nitrogen (TN) in the sediment were determined using a total organic carbon analyzer (TOC-VCPH, Shimadzu, Japan). TOC was determined on sieved sediments after acidification with $1 \mathrm{~mol} \mathrm{~L}^{-1} \mathrm{HCl},(16 \mathrm{~h})$, whereas samples for TN were not acidified (Kao et al., 2003). Sediment particle size was measured using a laser particle size analyzer (Malvern, 2000F, Malvern, UK) and associated metals (JH sediments) determined using High Definition X-Ray Fluorescence (HDRocksand тм, XOS, US). Particle size groupings were less than $4 \mu \mathrm{m}$ for clay, $4-63 \mu \mathrm{m}$ for silt and larger than $63 \mu \mathrm{m}$ for sand. TP in the sediments was determined via a $1 \mathrm{~mol} \mathrm{~L}^{-1} \mathrm{HCl}$ extraction $(16 \mathrm{~h}$ ) after undergoing calcination for $3 \mathrm{~h}$ in a muffle furnace at $550{ }^{\circ} \mathrm{C}$. The IP was determined by extraction with $1 \mathrm{~mol} \mathrm{~L}^{-1} \mathrm{HCl}$ for $16 \mathrm{~h}$ without calcination. The OP concentration in the sediment was calculated as the difference between the TP and IP (Aspila et al., 1976). The APA of the sediments was expressed by determining the hydrolysis of pnitrophenol phosphate (Hadas and Pinkas, 1997). For chlorophyll $a$ (Chl $a$ ), fresh wet sediment was extracted with $80 \%(\mathrm{v} / \mathrm{v})$ acetone for $12-24 \mathrm{~h}$ at $4{ }^{\circ} \mathrm{C}$ in the dark and the supernatant analyzed via a spectrophotometric method at $663 \mathrm{~nm}$ and $645 \mathrm{~nm}$ (Arnon, 1949).

\subsection{Phosphorus fractionation by the SMT}

Sedimentary P fractions were isolated using the SMT method 
(Ruban et al., 2001) and P concentration analyzed by the molybdenum blue method (Murphy and Riley, 1962). For TP, $0.2 \mathrm{~g}$ lyophilized sediments were calcined at $450{ }^{\circ} \mathrm{C}$ for $3 \mathrm{~h}$ and then extracted with $20 \mathrm{~mL} 3.5 \mathrm{~mol} \mathrm{~L}^{-1} \mathrm{HCl}$ in a shaking bath at $200 \mathrm{rpm}$ for $16 \mathrm{~h}$ and the extracts centrifuged at $2000 \times \mathrm{g}$ for $15 \mathrm{~min}$. For IP, $0.2 \mathrm{~g}$ sediments were extracted using $20 \mathrm{~mL} 1 \mathrm{~mol} \mathrm{~L}^{-1} \mathrm{HCl}$ for $16 \mathrm{~h}$. The residue from the IP extracts was baked at $450^{\circ} \mathrm{C}$ for $1 \mathrm{~h}$, and then further extracted with $1 \mathrm{~mol} \mathrm{~L}^{-1} \mathrm{HCl}$ for $16 \mathrm{~h}$, and the extract was centrifuged for OP determination. For $\mathrm{NaOH}-\mathrm{P}, 0.2 \mathrm{~g}$ sediments were extracted with $20 \mathrm{~mL} 1 \mathrm{~mol} \mathrm{~L}^{-1} \mathrm{NaOH}$ for $16 \mathrm{~h}$ and then centrifuged at $2000 \times \mathrm{g}$ for $15 \mathrm{~min}$. A $10 \mathrm{~mL}$ aliquot of the supernatant was placed in a $15 \mathrm{~mL}$ centrifuge tube and $4 \mathrm{~mL}^{3} .5 \mathrm{~mol} \mathrm{~L}^{-1} \mathrm{HCl}$ added to each. Subsequently, the tubes were shaken vigorously for $20 \mathrm{~s}$ and then allowed to stand for $16 \mathrm{~h}$ to form a precipitate. The tubes were centrifuged at $2000 \times g$ for $15 \mathrm{~min}$ and the supernatant collected for $\mathrm{NaOH}-\mathrm{P}$ analysis $\mathrm{HCl}-\mathrm{P}$ was determined by adding $20 \mathrm{~mL} 1 \mathrm{~mol} \mathrm{~L}^{-1} \mathrm{HCl}$ to the residue from the $\mathrm{NaOH}-\mathrm{P}$ extraction after washing with $1 \mathrm{~mol} \mathrm{~L}^{-1} \mathrm{NaCl}$. The tube was centrifuged at $2000 \mathrm{~g}$ for $15 \mathrm{~min}$ and the supernatant collected for analysis.

\subsection{The sequential extraction of $O P$}

The sedimentary OP was sequentially extracted with the optimized Ivanoff method (Zhao et al., 2018). Using this technique the OP is categorized as readily labile, moderately labile and non-labile but these are potential reactivity designations, rather than true measures of any activity in sediments. To determine readily labile $\mathrm{OP}, 1 \mathrm{~g}$ of sediment was extracted with $50 \mathrm{~mL} 0.5 \mathrm{~mol} \mathrm{~L}^{-1} \mathrm{NaHCO}_{3}$ in a shaking bath at $200 \mathrm{rpm}$ for $16 \mathrm{~h}$. After centrifugation, the IP and $\mathrm{TP}$ in the supernatant were determined. The difference between the TP and IP was the readily labile OP. For moderately labile OP, the residue from the readily labile OP extraction was extracted again with $1 \mathrm{~mol} \mathrm{~L}^{-1} \mathrm{HCl}$ in a shaking bath at $200 \mathrm{rpm}$ for $3 \mathrm{~h}$, centrifuged and the supernatant analyzed for $\mathrm{HCl}-\mathrm{OP}$. The residue from the $\mathrm{HCl}$ extraction was subsequently washed with deionized water and then extracted with $0.5 \mathrm{~mol} \mathrm{~L}^{-1} \mathrm{NaOH}$ in a shaking bath at $200 \mathrm{rpm}$ for $16 \mathrm{~h}$. After centrifugation, the supernatant was acidified to a $\mathrm{pH}$ of 0.2 to separate the moderately labile $\mathrm{OP}$ (fulvic acid-OP) from the non-labile OP. The HCl-OP and fulvic acid-OP constituted the moderately labile OP. To determine the non-labile OP, the residue from the $\mathrm{NaOH}$ extraction was calcined at $550^{\circ} \mathrm{C}$ for $1 \mathrm{~h}$ and the ash extracted with $1 \mathrm{~mol} \mathrm{~L}^{-1} \mathrm{H}_{2} \mathrm{SO}_{4}$ at $200 \mathrm{rpm}$ for $24 \mathrm{~h}$. The $\mathrm{H}_{2} \mathrm{SO}_{4}-\mathrm{OP}$ and humic acid-OP in the supernatant constituted the non-labile OP. A $\mathrm{K}_{2} \mathrm{~S}_{2} \mathrm{O}_{8}+\mathrm{H}_{2} \mathrm{SO}_{4}$ digestion system was selected to measure the TP in all extracts (Zhao et al., 2018).

\subsection{NaOH-EDTA extraction and ${ }^{31} \mathrm{P}-\mathrm{NMR}$ determination}

Weighed $3 \mathrm{~g}$ of lyophilized sediment were extracted with $30 \mathrm{~mL}$ $0.25 \mathrm{~mol} \mathrm{~L}^{-1} \mathrm{NaOH}+50 \mathrm{mmol} \mathrm{L}^{-1} \mathrm{Na}_{2}$ EDTA by shaking for $16 \mathrm{~h}$ (Cade-Menun and Preston, 1996). The extracts were centrifuged, and the supernatant collected to be measured for TP and IP. TP in the extracts was determined after digestion with $\mathrm{K}_{2} \mathrm{~S}_{2} \mathrm{O}_{8}+\mathrm{H}_{2} \mathrm{SO}_{4}$ in an autoclave at $121^{\circ} \mathrm{C}$ for $30 \mathrm{~min}$. The IP in extracts was measured without digestion. OP content in extracts was calculated as the difference between the concentrations of TP and IP. The recovery (Rec.) of TP was calculated as the ratio of the total extracted TP (TEP) to the TP in the sediment. The recovery of OP was calculated as the ratio of the total extracted OP (TEOP) to the OP in the sediment. The remainder of the extract was lyophilized for $24-48 \mathrm{~h}$ to obtain the dry extracts. Subsequently, $0.6 \mathrm{~mL} \mathrm{D}_{2} \mathrm{O}$ and $0.1 \mathrm{~mL}$ $10 \mathrm{~mol} \mathrm{~L}^{-1} \mathrm{NaOH}$ were successively added to the lyophilized extracts (200-300 mg); vortexed and centrifuged at $14,000 \mathrm{rpm}$ for $20 \mathrm{~min}$ at $4{ }^{\circ} \mathrm{C}$. The resulting supernatant was added to a $5-\mathrm{mm}$ NMR tube within approximately $10 \mathrm{~min}$ for soluble ${ }^{31} \mathrm{P}-\mathrm{NMR}$ spectral analysis using an Advance III Bruker $500 \mathrm{MHz}$ spectrometer (Germany) at $202.47 \mathrm{MHz}$. After ${ }^{31} \mathrm{P}-\mathrm{NMR}$ spectroscopy, the reconstituted sample was analyzed for total $\mathrm{P}, \mathrm{Fe}$, and $\mathrm{Mn}\left(\mathrm{mg} \mathrm{L}^{-1}\right)$ by inductively coupled plasma-mass adsorption spectroscopy (Perkin-Elmer Optima 7000 DV, USA) after digestion by aqua regia. The NMR delay times were determined based on the ratio of concentrations of $\mathrm{P} /(\mathrm{Fe}+\mathrm{Mn})(\mathrm{w} / \mathrm{v})$ within the extracts (McDowell et al., 2006). A pulse of $45^{\circ}$, an acquisition time of $0.68 \mathrm{~s}$, a pulse delay of 4.32 , a temperature of $20^{\circ} \mathrm{C}$, and $\sim 10,000$ scans were used. The ${ }^{31} \mathrm{P}-\mathrm{NMR}$ spectral measurement was conducted at the Analysis and Testing Center of Yantai Institute of Coastal Zone Research, CAS.

The signal of the $\mathrm{P}$ species spectrum was identified and quantified based on spiking experiments and relative chemical shifts from published data with the orthophosphate peak in all spectra standardized to $6 \mathrm{ppm}$ (Cade-Menun, 2005, 2015). Lyophilized $\mathrm{NaOH}$-EDTA samples spiked with $\beta$-glycerophosphate disodium salt hydrate and DL- $\alpha$-glycerol phosphate (Sigma numbers, G5422 and 17766, respectively), adenosine 5' monophosphate disodium salt (Sigma number, 01930), $\alpha$-D-Glucose 1 -phosphate disodium salt hydrate (Sigma number, G7018) and glyphosate (Sigma number, 45521). Spiked samples were analyzed by ${ }^{31} \mathrm{P}-\mathrm{NMR}$ as described above. The spectra were processed with $10 \mathrm{~Hz}$ line broadening for full spectra and a $1 \mathrm{~Hz}$ line broadening for analyzing the fine details of the specific regions ( $7 \mathrm{ppm}-2.5 \mathrm{ppm}$ and $2.5 \mathrm{ppm}$ to $-4.5 \mathrm{ppm}$ ).

\subsection{SEM-EDS analysis of the metallic oxides in JL sediments}

Metallic oxides in surface sediment samples JL1, JL6 and JL9 were analyzed with a high resolution field emission scanning electron microscope (SEM, S-4800, Hitachi, Japan) and energy dispersive X-ray micro-analyzer (EDS, EX-350, HORIBA, Japan). The elemental mapping was performed with an acceleration voltage of $15 \mathrm{kV}$. The relative abundance of the top five metals and oxygen in the sediments were estimated using the Aztec software.

\subsection{Statistical analysis}

Statistical analysis was performed with the SPSS 19 software package (SPSS Inc., USA). The one-way analysis of variance was conducted with Welch's ANOVA and followed by a Games-Howell (A) test at a significance level of $>0.05$. The data distributed abnormally have been normalized with centered log ratio transformations prior to conducting the ANOVA (Abdi et al., 2015). A Pearson correlation analysis was conducted. Principal component analysis (PCA) was employed to assess the input source of each P fraction. The first two principle components (PCs) with eigenvalues of $>1$ were retained and considered to be the most significant factors. All ${ }^{31} \mathrm{P}-\mathrm{NMR}$ spectra were processed using the Bruker Software (TopSpin 3.5, Germany). All samples were tested in three parallel experiments, and the results were expressed as the mean values. The relative standard deviation (RSD) of the determinations was $\leq 5 \%$.

\section{Results}

\subsection{Characteristics of the overlying water and sediments}

General water column parameters are given in Table 1 . The average temperature $(\mathrm{T})$ ranged between $26^{\circ} \mathrm{C}$ and $32^{\circ} \mathrm{C}$. The DO and $\mathrm{pH}$ ranged from $2.27 \mathrm{mg} \mathrm{L}^{-1}$ to $5.42 \mathrm{mg} \mathrm{L}^{-1}$ and 2.83 to 7.55 , respectively. The conductivity (Cond.) was high and had a significantly positive correlation with the salinity $(r=0.996, p<0.01)$. The JL had an abnormally high salinity that strongly fluctuated between 13.6 PSU and 56.1 PSU (mean 42.9 \pm 13.3 PSU) with the 
Table 1

The physical and chemical properties of the overlying water onshore and offshore of the JL and JH sampling sites.

\begin{tabular}{|c|c|c|c|c|c|c|}
\hline Sampling sites & $\mathrm{T}^{1}\left({ }^{\circ} \mathrm{C}\right)$ & $\mathrm{DO}^{2}\left(\mathrm{mg} \mathrm{L}^{-1}\right)$ & Cond. $^{3}\left(\mathrm{~ms} \mathrm{~cm}^{-1}\right)$ & Sal. $^{4}$ (PSU) & $\mathrm{pH}$ & $\mathrm{ORP}^{5}(\mathrm{mv})$ \\
\hline JL1 & 29.6 & 5.42 & 68.2 & 42.0 & 6.65 & 354.1 \\
\hline JL2 & 29.7 & 4.01 & 78.0 & 49.0 & 4.94 & 536.9 \\
\hline JL3 & 30.0 & 3.13 & 79.8 & 50.0 & 3.86 & 724.7 \\
\hline JL4 & 30.1 & 2.97 & 81.0 & 50.8 & 3.39 & 752.3 \\
\hline JL5 & 30.6 & 2.27 & 84.9 & 52.9 & 2.89 & 792.1 \\
\hline JL6 & 31.9 & 3.61 & 91.0 & 56.1 & 2.52 & 812.7 \\
\hline JL7 & 35.3 & 4.04 & 90.8 & 50.8 & 2.83 & 791.8 \\
\hline JL8 & 36.5 & 4.40 & 57.5 & 30.3 & 3.58 & 710.3 \\
\hline JL9 & 33.2 & 5.20 & 26.4 & 13.6 & 6.15 & 487.8 \\
\hline JL10 & 34.0 & 4.46 & 60.1 & 33.5 & 7.55 & 480.9 \\
\hline L1 & 26.6 & 6.72 & 49.7 & 31.4 & 8.21 & 385.5 \\
\hline L2 & 26.8 & 6.75 & 49.8 & 31.4 & 8.20 & 385.6 \\
\hline L3 & 26.6 & 6.81 & 49.7 & 31.4 & 8.18 & 388.3 \\
\hline L4 & 26.7 & 6.83 & 49.6 & 31.3 & 8.10 & 390.5 \\
\hline L5 & 25.9 & 6.92 & 49.2 & 31.4 & 8.10 & 394.7 \\
\hline L6 & 26.3 & 6.83 & 49.4 & 31.4 & 8.20 & 390.3 \\
\hline L7 & 25.8 & 7.14 & 49.0 & 31.4 & 7.94 & 394.3 \\
\hline L8 & 26.3 & 6.88 & 49.4 & 31.4 & 8.18 & 387.6 \\
\hline L9 & 25.8 & 7.04 & 49.2 & 31.6 & 7.78 & 406.9 \\
\hline $\mathrm{K}$ & 25.6 & 7.17 & 49.1 & 31.7 & 7.37 & 402.9 \\
\hline $\mathrm{JH} 1$ & 29.9 & 7.66 & 2.6 & 1.21 & 8.20 & 420.3 \\
\hline $\mathrm{JH} 2$ & 29.9 & 6.70 & 2.7 & 1.24 & 7.92 & 394.6 \\
\hline JH3 & 29.9 & 7.64 & 2.7 & 1.25 & 7.66 & 386.6 \\
\hline $\mathrm{JH} 4$ & 26.9 & 6.92 & 2.05 & 1.00 & 6.53 & 442.8 \\
\hline JH5 & 27.6 & 7.65 & 2.08 & 1.00 & 7.45 & 419.5 \\
\hline JH6 & 26.4 & 6.22 & 1.99 & 0.98 & 7.61 & 404.2 \\
\hline $\mathrm{J} 1$ & 25.9 & 7.59 & 50.0 & 32.0 & 7.96 & 390.4 \\
\hline $\mathrm{J} 2$ & 26.4 & 7.50 & 50.3 & 32.0 & 7.92 & 391.8 \\
\hline J3 & 26.3 & 7.63 & 50.2 & 32.1 & 7.83 & 394.1 \\
\hline $\mathrm{J} 4$ & 26.3 & 7.69 & 50.3 & 32.0 & 7.84 & 394.3 \\
\hline J5 & 25.9 & 7.69 & 50.0 & 32.1 & 7.82 & 391.7 \\
\hline J6 & 25.7 & 7.68 & 49.7 & 32.1 & 7.80 & 390.7 \\
\hline J7 & 25.5 & 7.51 & 49.5 & 32.0 & 7.33 & 393.2 \\
\hline
\end{tabular}

Note, 1: Temperature; 2, Dissolved Oxygen; 3, Conductivity; 4, Salinity; 5, Oxidation Reduction Potential.

maximum approximately 1.5 -fold higher than in the offshore areas (average $31.7 \mathrm{PSU}$ ). Compared to the JL, the JH was a freshwater river (mean salinity, $1.11 \pm 0.13 \mathrm{PSU}$ ). In addition, the ORP of the JL onshore areas varied from $354 \mathrm{mv}$ to $812 \mathrm{mv}$ (mean, $644 \pm 163 \mathrm{mv}$ ). It was approximately 1.6-fold higher than at the other sites (mean, $397 \pm 13.7 \mathrm{mv}$ ).

The average sediment content of TOC, TN, APA and Chl $a$ in the rivers were higher than those offshore (Table 2, Fig. S2), and those in the $\mathrm{JH}$ were higher than those in the JL. Furthermore, the respective TP and OP values in the JH were $1785 \pm 703 \mathrm{mg} \mathrm{kg}^{-1}$ and $221 \pm 104 \mathrm{mg} \mathrm{kg}^{-1}$. In the offshore sediments, the respective TP and OP values were $439 \pm 34.0 \mathrm{mg} \mathrm{kg}^{-1}$ and $49.0 \pm 7.00 \mathrm{mg} \mathrm{kg}^{-1}$. Compared to JH and the offshore sediments, the TP and OP content were relatively low, with mean values of $463 \pm 69.0 \mathrm{mg} \mathrm{kg}^{-1}$ and $73.0 \pm 51.0 \mathrm{mg} \mathrm{kg}^{-1}$ in the JL and $350 \pm 53.0 \mathrm{mg} \mathrm{kg}^{-1}$ and $50.0 \pm 9.00 \mathrm{mg} \mathrm{kg}^{-1}$ in the offshore sediments, respectively. In Fig. S2, sand dominated the particle size in the JL $(67.7 \pm 13.1 \%)$ and the offshore sediments $(81.8 \pm 15.0 \%)$ except for JL10. However, the $\mathrm{JH}$ and offshore sediments were mainly composed of silt, except for JH6. The mean percentages of silt in the $\mathrm{JH}$ and offshore were $47.6 \pm 21.9 \%$ and $54.6 \pm 7.70 \%$, respectively.

\subsection{Phosphorus sequential extraction of the sediments by SMT}

Sequential extraction of $\mathrm{P}$ by SMT is illustrated in Fig. 1. The average TP concentrations of the two river sediments were higher than those of the offshore sediments $\left(\mathrm{JH}, 1713 \pm 679 \mathrm{mg} \mathrm{kg}^{-1}>\mathrm{J}\right.$, $425 \pm 28.3 \mathrm{mg} \mathrm{kg}^{-1}$; JL, $442 \pm 82.0 \mathrm{mg} \mathrm{kg}^{-1}>\mathrm{L}, 332 \pm 47.0 \mathrm{mg} \mathrm{kg}^{-1}$ ), and the highest TP was present in the JH sediment. Generally, the IP was the dominant fraction of the TP. In this study, the HCl-P was the main component of the IP except in the JH sediments. The $\mathrm{HCl}-\mathrm{P}$ accounted for $70.6 \pm 11.3 \%, 28.0 \pm 11.2 \%, \quad 80.5 \pm 2.56 \%$ and $82.2 \pm 2.41 \%$ of the TP in the JL and JH onshore sediments and the JL and $\mathrm{JH}$ offshore sediments, respectively. The NaOH-P concentrations for the JL and $\mathrm{JH}$ offshore sediments were low and varied slightly, with average values of $13.2 \pm 4.36 \mathrm{mg} \mathrm{kg}^{-1}$ and $28.7 \pm 4.87 \mathrm{mg} \mathrm{kg}^{-1}$, respectively. The OP contents in the $\mathrm{JL}$ and $\mathrm{JH}$ offshore sediments were respectively $\sim 4$ and $\sim 2$-fold higher than those in the $\mathrm{JL}$ and $\mathrm{JH}$ offshore sediments. In addition, the OP concentrations varied slightly in the JL and JH offshore sediments, with respective mean values of $49.5 \pm 8.64 \mathrm{mg} \mathrm{kg}^{-1}$ and $48.6 \pm 7.49 \mathrm{mg} \mathrm{kg}^{-1}$. The $\mathrm{NaOH}-\mathrm{P}$ content of the JL sediments was low upstream (JL1 - JL4) and downstream (JL7 - JL10) but high midstream (JL5 - JL6). Compared to the NaOH-P, the distribution of OP content was relatively high in the upstream (JL1 - JL3) and downstream (JL7 - JL10) but was low midstream (JL4 - JL6). At the same time, the salinity was high in the overlying water between the JL5 and JL6 sites (Table 1). The NaOH-P was the major P fraction $(58.1 \pm 12.8 \%$ of the TP) in the JH sediments, but the OP was low (mean, $13.9 \pm 2.86 \%$ of the TP).

\subsection{The OP fractionation by the optimized Ivanoff method}

The concentrations and distributions of OP fractions are shown in Fig. 2. The total OP (TOP) represented the sum of the extracted $\mathrm{NaHCO}_{3}-\mathrm{OP}, \mathrm{HCl}-\mathrm{OP}$, Flv-OP, Hum-OP and $\mathrm{H}_{2} \mathrm{SO}_{4}$-OP. The TOP content in the JH sediments was $236 \pm 105 \mathrm{mg} \mathrm{kg}^{-1}$, which was $\sim 5$-fold higher than that in its offshore sediment. The mean TOP concentration in the JL sediments was $76.2 \pm 54.1 \mathrm{mg} \mathrm{kg}^{-1}$, which was approximately 1.5 -fold higher than that in the offshore sediment. 
Table 2

The physical and chemical properties of onshore and offshore sediments of the JL and JH sampling sites.

\begin{tabular}{|c|c|c|c|c|c|c|}
\hline Sampling sites & $\mathrm{TOC}^{\mathrm{a}}(\%)$ & $\mathrm{TN}^{\mathrm{b}}(\%)$ & $\mathrm{TP}^{\mathrm{C}}\left(\mathrm{mg} \mathrm{kg}^{-1}\right)$ & $\mathrm{OP}^{\mathrm{d}}\left(\mathrm{mg} \mathrm{kg}^{-1}\right)$ & $\mathrm{APA}^{\mathrm{e}}\left(\mathrm{mg} \mathrm{kg}^{-1} \mathrm{~h}^{-1}\right)$ & $\mathrm{Chl} a^{\mathrm{f}} \mathrm{mg} \mathrm{kg}^{-1}$ \\
\hline JL1 & 0.11 & 0.01 & 447 & 40.0 & 37.5 & 6.94 \\
\hline JL2 & 0.12 & 0.01 & 448 & 65.0 & 27.3 & 12.3 \\
\hline JL3 & 0.06 & 0.01 & 368 & 35.0 & 8.64 & 1.42 \\
\hline JL4 & 0.09 & 0.01 & 488 & 30.0 & 17.6 & 3.63 \\
\hline JL5 & 0.11 & 0.01 & 498 & 35.0 & 25.4 & 7.42 \\
\hline JL6 & 0.08 & 0.01 & 443 & 40.0 & 16.5 & 3.79 \\
\hline JL7 & 0.17 & 0.01 & 348 & 50.0 & 38.2 & 4.63 \\
\hline JL8 & 1.92 & 0.24 & 583 & 145 & 113.4 & 32.6 \\
\hline JL9 & 1.82 & 0.23 & 518 & 140 & 595.7 & 56.4 \\
\hline JL10 & 1.19 & 0.13 & 487 & 150 & 328.8 & 21.5 \\
\hline L1 & 0.08 & 0.01 & 428 & 40.0 & 55.0 & 1.17 \\
\hline L2 & 0.08 & 0.01 & 347 & 55.0 & 61.8 & 2.43 \\
\hline L3 & 0.07 & 0.01 & 293 & 45.0 & 39.08 & 0.82 \\
\hline L4 & 0.08 & 0.01 & 373 & 45.0 & 58.9 & 1.32 \\
\hline L5 & 0.06 & 0.02 & 377 & 55.0 & 60.9 & 1.11 \\
\hline L6 & 0.06 & 0.01 & 278 & 40.0 & 36.9 & 0.48 \\
\hline L7 & 0.06 & 0.01 & 333 & 40.0 & 32.0 & 0.46 \\
\hline L8 & 0.06 & 0.01 & 278 & 55.0 & 37.6 & 0.76 \\
\hline L9 & 0.06 & 0.01 & 353 & 65.0 & 32.0 & 0.70 \\
\hline $\mathrm{K}$ & 0.10 & 0.01 & 433 & 55.0 & 43.5 & 1.46 \\
\hline JH1 & 0.95 & 0.14 & 1917 & 130 & 109.8 & 21.9 \\
\hline $\mathrm{JH} 2$ & 0.90 & 0.09 & 1607 & 240 & 140.3 & 12.1 \\
\hline JH3 & 0.66 & 0.11 & 1197 & 190 & 97.2 & 9.61 \\
\hline $\mathrm{JH} 4$ & 1.23 & 0.18 & 2297 & 290 & 207.4 & 34.6 \\
\hline JH5 & 2.30 & 0.36 & 2797 & 380 & 589.3 & 43.7 \\
\hline JH6 & 0.38 & 0.02 & 897 & 100 & 58.8 & 6.76 \\
\hline $\mathrm{J} 1$ & 0.26 & 0.01 & 417 & 45.0 & 51.3 & 1.75 \\
\hline $\mathrm{J} 2$ & 0.11 & 0.01 & 438 & 55.0 & 62.1 & 2.84 \\
\hline $\mathrm{J} 3$ & 0.11 & 0.01 & 407 & 40.0 & 47.2 & 2.12 \\
\hline J4 & 0.12 & 0.01 & 478 & 60.0 & 54.4 & 1.77 \\
\hline J5 & 0.20 & 0.03 & 448 & 50.0 & 75.9 & 1.77 \\
\hline J6 & 0.13 & 0.03 & 483 & 50.0 & 48.3 & 1.60 \\
\hline J7 & 0.09 & 0.01 & 397 & 40.0 & 47.1 & 0.63 \\
\hline
\end{tabular}

Note, a: Total organic carbon; b, Total nitrogen; c, Total phosphorus; e, Alkaline phosphatase activity; f, chlorophyll a.

Additionally, the TOP was mainly composed of non-labile OP, with respective average concentrations of $52.7 \pm 38.9 \mathrm{mg} \mathrm{kg}^{-1}$, $133 \pm 54.0 \mathrm{mg} \mathrm{kg}^{-1}, 36.9 \pm 3.80 \mathrm{mg} \mathrm{kg}^{-1}$ and $36.6 \pm 5.30 \mathrm{mg} \mathrm{kg}^{-1}$ in the JL and JH onshore sediments and the JL and JH offshore sediments. The mean relative contributions of the TOP in the JL and JH onshore sediments and the JL and JH offshore sediments were $69.9 \pm 9.60 \%, 56.8 \pm 10.2 \%, 72.6 \pm 8.80 \%$ and $78.0 \pm 7.00 \%$, respectively. The moderately labile OP was next most abundant, with mean concentrations accounting for $20.0 \pm 9.20 \%, 33.3 \pm 9.70 \%$, $23.6 \pm 9.10 \%$ and $11.5 \pm 5.50 \%$ of TOP in the JL and JH onshore sediments and the JL and JH offshore sediments, respectively. The readily labile OP had the lowest values, with mean concentrations accounting for less than $10.0 \%$ of the TOP in the onshore and offshore sediments of both rivers. Furthermore, $\mathrm{H}_{2} \mathrm{SO}_{4}-\mathrm{OP}$ dominated the non-labile OP, accounting for $50.4 \pm 14.1 \%$, $32.6 \pm 14.0 \%$, $54.1 \pm 6.00 \%$ and $55.4 \pm 7.30 \%$ of the TOP in the JL and JH onshore sediments and the JL and JH offshore sediments, respectively. FlvOP was the predominant fraction in the moderately labile OP of the $\mathrm{JL}$ and $\mathrm{JH}$ onshore sediments and the JH offshore sediments, accounting for $4.10 \%-19.5 \%, 13.2-24.6 \%$, and $0-12.8 \%$ of the TOP, respectively. However, $\mathrm{HCl}-\mathrm{OP}$ was the major fraction in the moderately labile OP, and it was generally three-fold higher than that in the Flv-OP, accounting for $5.40-33.2 \%$ of the total OP (mean, $17.8 \pm 8.10 \%)$ in the JL offshore sediments.

\section{4. ${ }^{31} \mathrm{P}-\mathrm{NMR}$ spectra of $\mathrm{NaOH}-\mathrm{EDTA}$ extracts}

Nine representative sediment samples (JL5, JL9; L1, K; JH1, JH3, JH5; J1, J6) were selected for the ${ }^{31}$ P-NMR determination. These samples were selected from upstream to downstream and into the Bohai Sea along the JL and JH rivers. The NMR spectra, and the recoveries of TP and OP in the extracts are shown in Fig. 3 and Table S6, respectively. Based on the spiking experiments, details of orthophosphate monoesters and diesters in sediments were identified and quantified (Table 3, Fig. S3). The areas of total orthophosphate monoesters and diesters were collected based on the spiking experiments because the RNA and phospholipids can be degraded into the mononucleotides, $\alpha$ - and $\beta$-glycerophosphate, respectively. Generally, there was a greater variety of $\mathrm{P}$ containing compounds in the $\mathrm{JH}$ onshore sediments than in the JL onshore sediments. The JH5 sampling sites had the most (three compound groups and four compounds). There was also a range of compounds in sampling site JL9 with low salinity than those in sampling site JL5 with high salinity. Furthermore, the results demonstrated that orthophosphate (ortho-P) was the main compound in all of the $\mathrm{NaOH}$-EDTA extracts of the onshore and offshore sediments of both rivers. Generally, orthophosphate diester was the major component of $\mathrm{OP}$ in the onshore sediment extracts. The DNA-P was only detected in onshore sediments (JL9, JH1, JH3 and JH5) in both rivers. Pyrophosphate was also an IP type detected only in the onshore sediments (JL5, JL9, JH1 and JH5) of both rivers. Polyphosphate was not detected in any of the sediment extracts. Only the orth-P was determined in the offshore sediments. Noticeably, there was greater diversity at the JH5 sampling site, including two more types of $\mathrm{P}$ containing compounds, i.e., phosphonate $(0.50 \%)$ and unknown peak $(0.80 \%)$. The recoveries of TP and OP in the extracts of $\mathrm{JH}$ onshore sediments varied from $60.2 \%$ to $94.6 \%$ and $36.8 \%-81.1 \%$, respectively. The lowest recoveries of TP and OP appeared in the two river's offshore sediments (approximate 9\%). The recoveries of TP and OP in the JL9 sediment (low salinity) were both 1.6-fold higher than that in the JL5 sediment (high salinity). 

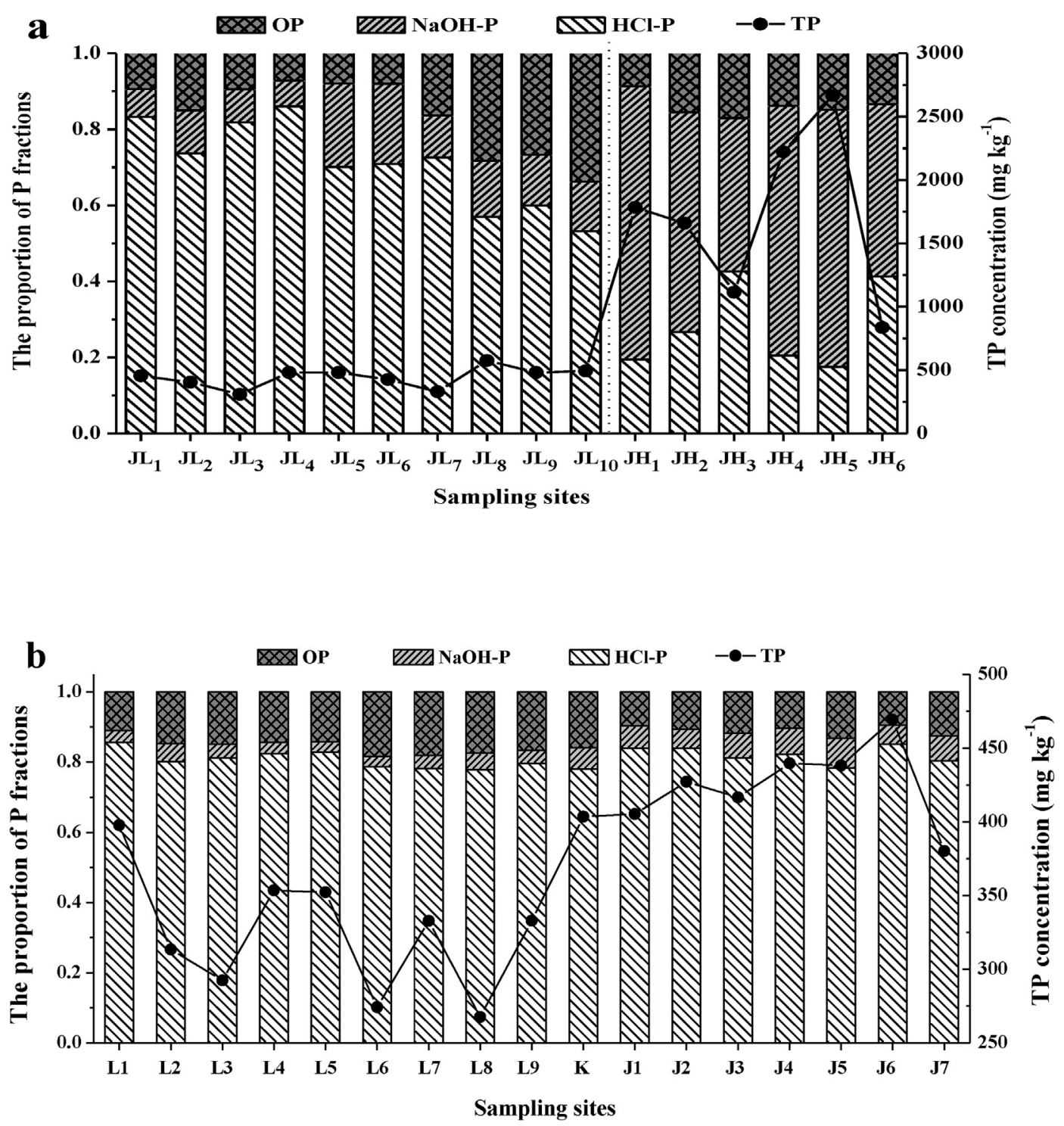

Fig. 1. The proportion of the P fractions in the rivers (a) and offshore sediments (b) by the SMT protocol. OP, organic phosphorus (P); $\mathrm{HCl}-\mathrm{P}, \mathrm{HCl}$ extractable P; NaOH-P, NaOH soluble P.

\subsection{Principal component analysis}

Fig. 4 shows that compositions of the P fractions and environmental factors differ significantly across the thirty sediment samples. Eighty-seven percent of the variance in the sedimentary composition was explained by the first two PCs (PC1:77\%, PC2:10\%). Factor 1 was heavily weighted with TP, NaOH-P and $\mathrm{HCl}-\mathrm{P}$. Factor 2 had a significant positive loading of APA, Chl $a$, TOC and TN. Various OP were just located the middle of the factor 1 and 2 .

\section{Discussion}

\subsection{Potential sources and composition analysis}

PCA was conducted to gain an insight into the contributions of various sources of $\mathrm{P}$ and how this related to environmental factors in the sediments. Previous reports have stated that indigenous phytoplankton and bacteria can excrete extracellular alkaline phosphatase to hydrolyze OP into active $\mathrm{PO}_{4}^{3-}$ for uptake (Feng et al., 2018; Labry et al., 2016). Thus, factor 2 in our analysis represents a significant contribution from indigenous biological sources. However, high TP concentrations were mainly due to anthropogenic inputs, and the large amounts of $P$ accumulated in the sediment (Owens and Walling, 2002). Factor 1 exhibited a high loading of TP, which suggests that anthropogenic inputs could possibly be a source of $\mathrm{HCl}-\mathrm{P}, \mathrm{NaOH}-\mathrm{P}$ and TP. However, the OP fractions in the elliptic region " $b$ " had low loading from both factors, indicating different sources or environmental factors than for the compositions of the elliptic regions "a" and "c". Additionally, the ${ }^{31} \mathrm{P}-\mathrm{NMR}$ spectrum results demonstrate that most of the OP was Mono-P, which is a dominant form of $\mathrm{P}$ in macrophytes and algae (Feng et al., 2016). However, organophosphate ester (mono-, diand triester) pesticides and organophosphorus flame retardants are also two OP types of anthropogenic pollutant, which have been found in sediments in the coastal Laizhou bay area of the Bohai Sea (Wang et al., 2017a, b). The two rivers in the present study are located just inside the Laizhou bay. Therefore, both indigenous biological and anthropogenic inputs are possibly significant OP sources in the sediment, and the elliptic region "b" had low loads in both factors (Fig. 4). 

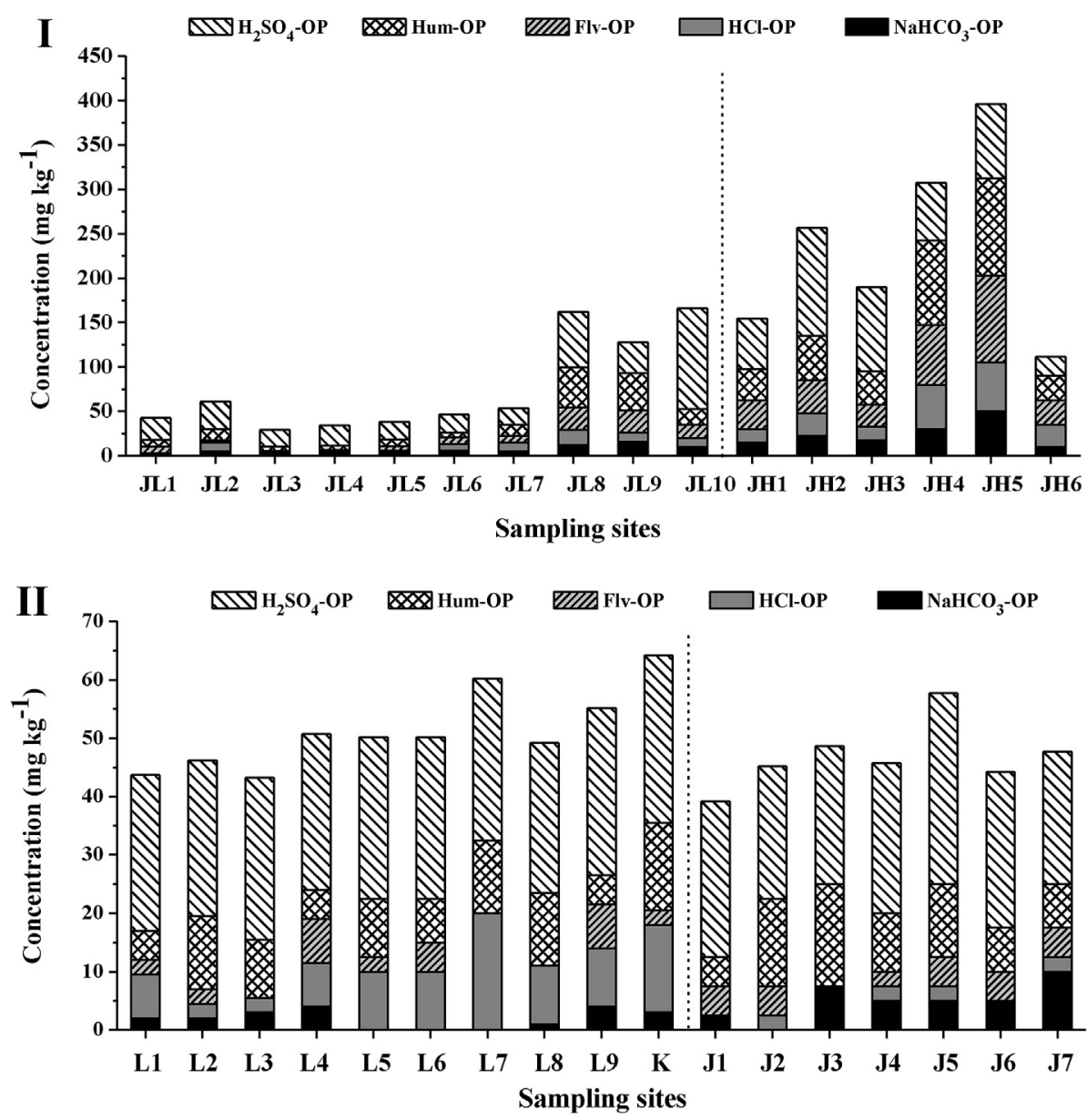

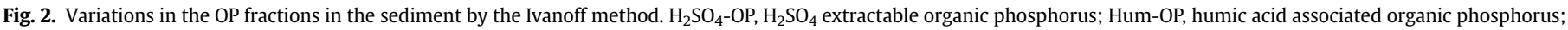
Flv-OP, fulvic acid associated organic phosphorus; $\mathrm{HCl}-\mathrm{OP}, \mathrm{HCl}$ soluble organic phosphorus; $\mathrm{NaHCO}_{3}-\mathrm{OP}, \mathrm{NaHCO}_{3}$ extractable organic phosphorus.

\subsection{Biogeochemical behaviors of $P$}

The JL is a high-salinity river, and offshore sediments adjacent to both JL and JH lie within the Bohai Sea. However, the high salt content in the JL is not caused by seawater intrusion but industrial emissions thus, the mechanisms accounting for the biogeochemical characteristics of $\mathrm{P}$ in the JL should be different from those in the $\mathrm{JH}$, $\mathrm{L}$ and $\mathrm{J}$ sediments. It is, therefore, important to elucidate the biogeochemical cycle of $\mathrm{P}$ under high industrial salinity stress as this could affect some physicochemical properties of the overlying water, which in turn could affect the transformation of $P$ (Gardolinski et al., 2004). The end of spring and summer are usually the solar salt seasons and the amount of wastewater discharged from salt fields on both sides of the JL is generally much greater during this period than in other seasons. Thus, the salinity and $\mathrm{pH}$ in the JL overlying water have obvious seasonal characteristics due to the amount of wastewater discharged (Tables S1-S4). Salinity in the JL had a negative correlation with $\mathrm{pH}(\mathrm{r}=-0.694, \mathrm{p}<0.05)$, which probably illustrates that the discharges from the salt fields contain abundant hydrogen and oxidizing ions. However, the $\mathrm{HCl}$ extractable P was primarily composed of Ca-P, which is potentially stable and has little risk of release (Ruttenberg and Berner, 1993; Shan et al., 2016). However, the acidic overlying water ( $\mathrm{pH}$ mean, $4.09 \pm 1.49$ ) could potentially result in dissolution of $\mathrm{P}$ from $\mathrm{CaCO}_{3} /$ CaO-P (Yang et al., 2016). The SEM-EDS results show a significant correlation between $\mathrm{Ca}, \mathrm{O}$ and $\mathrm{S}$ (Fig. 5), thus the majority of calcium compounds are probably present as $\mathrm{CaSO}_{4}$ in the $\mathrm{JL}$ onshore sediments. Previous reports have suggested that $\mathrm{CaSO}_{4}$ was the dominant sulfate mineral in river and lake sediments that could be stable at low $\mathrm{pH}(\mathrm{pH} \sim 3)$ (Mi et al., 2018). Thus, there was still abundant $\mathrm{HCl}-\mathrm{P}$ in the JL onshore sediments even with relatively low $\mathrm{pH}$ values due to most of the $\mathrm{HCl}-\mathrm{P}$ likely to be $\mathrm{CaSO}_{4}-\mathrm{P}$ rather than $\mathrm{CaCO}_{3}-\mathrm{P}$ and/or CaO-P. Additionally, the ORP was abnormally high, but DO in the overlying water was low in the JL onshore sediments. The Pearson analysis results indicated that the ORP had a significantly negative correlation with the DO in the JL overlying water $(r=-0.788, p<0.01)$ and the ORP is an index that correlates with redox levels. However, DO is only one of many factors that can affect ORP as there are abundant oxidizing components (e.g. $\mathrm{H}_{2} \mathrm{O}_{2}$, $\mathrm{O}_{3}, \mathrm{MnO}_{4}^{-}$) that can increase the ORP (Yang et al., 2001) and there are likely to be many oxidizing ions in the highly saline discharge to the JL. Published studies have demonstrated that metal-oxide bound $\mathrm{P}$ plays an important role in sedimentary processes releasing P to the overlying water (Wang et al., 2006). The relative abundance of aluminum (5.70\%) was slightly high at the JL6 site based on the SEM-EDS results (Fig. 5). There were relatively high ORP, low TOC and pH in the JL6 sediment. Previous studies have reported that most aluminum was mainly associated with the residual fraction, which was the dominant metal fraction in the sediments (Nasr et al., 2018). In acidic conditions with oxidizing, low organic matter and frequent cycles of wetting and drying, the metal (hydro) oxide in surface sediments would be hydroxyl Al, including Si (Al-O-Si) (Matsue and Wada, 1989). Additionally, Story et al. (2010) observed that high salinity in the overlying water 

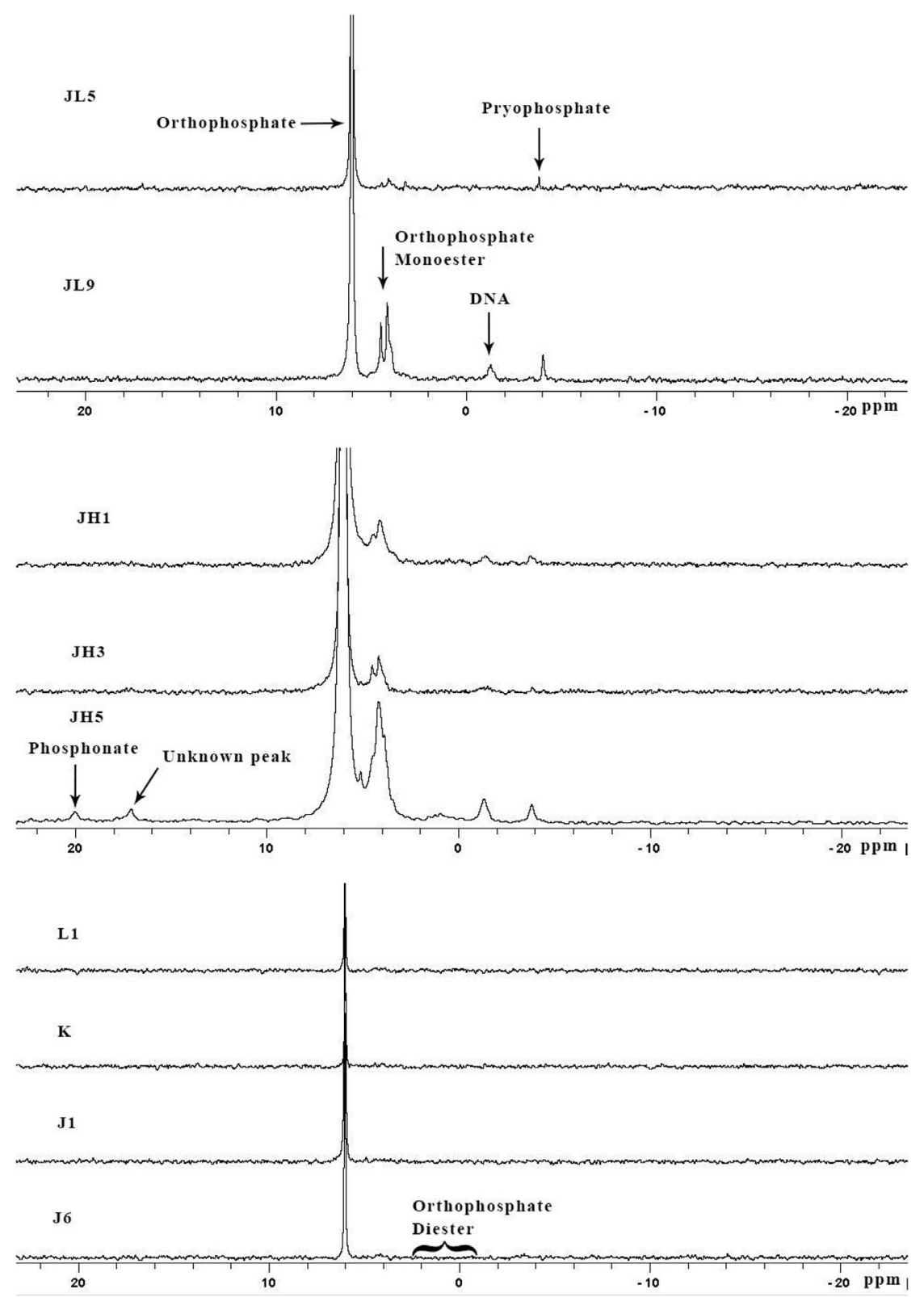

Fig. 3. ${ }^{31} \mathrm{P}-\mathrm{NMR}$ spectra of the $\mathrm{NaOH}$ - EDTA extracts of the surface sediments.

Table 3

The relative distribution of phosphorus species determined by ${ }^{31} \mathrm{P}-\mathrm{NMR}$ spectroscopy in the NaOH-EDTA extracts.

\begin{tabular}{|c|c|c|c|c|c|c|c|c|}
\hline \multirow[t]{2}{*}{ Sediments } & \multicolumn{8}{|c|}{ Integral Area (\%) } \\
\hline & Phosphonate & Unknown & Ortho-P & Mono-P & Dies-P & DNA & Pyrophosphate & Polyphosphate \\
\hline JL5 & n.d. & n.d. & $83.4 \%$ & $2.02 \%$ & $1.58 \%$ & n.d. & $0.7 \%$ & n.d. \\
\hline JL9 & n.d. & n.d. & $67.9 \%$ & $10.1 \%$ & $14.5 \%$ & $3.56 \%$ & $2.65 \%$ & n.d. \\
\hline $\mathrm{JH} 1$ & n.d. & n.d. & $85.7 \%$ & $2.82 \%$ & $6.18 \%$ & $1.0 \%$ & $1.1 \%$ & n.d. \\
\hline JH3 & n.d. & n.d. & $83.1 \%$ & $1.00 \%$ & $4.30 \%$ & $0.4 \%$ & n.d. & n.d. \\
\hline JH5 & $0.5 \%$ & $0.8 \%$ & $74.0 \%$ & $4.40 \%$ & $14.8 \%$ & $1.4 \%$ & $0.6 \%$ & n.d. \\
\hline L1 & n.d. & n.d. & $91.0 \%$ & n.d. & n.d. & n.d. & n.d. & n.d. \\
\hline $\mathrm{K}$ & n.d. & n.d. & $92.1 \%$ & n.d. & n.d. & n.d. & n.d. & n.d. \\
\hline $\mathrm{J} 1$ & n.d. & n.d. & $92.6 \%$ & n.d. & n.d. & n.d. & n.d. & n.d. \\
\hline J6 & n.d. & n.d. & $90.5 \%$ & n.d. & n.d. & n.d. & n.d. & n.d. \\
\hline
\end{tabular}

Note, n.d.: not detected or below the LOQs. Ortho-P, orthophosphate; Mono-P, orthophosphate monoesters; Dies-P, orthophosphate diesters.

column could inhibit degradation of $\mathrm{Fe} / \mathrm{Mg}$-Si oxides under conditions of low $\mathrm{pH}(2.50-5.40)$. In this work, results for sediment JL6 are in agreement with the above conclusion as results (elemental EDS maps) show a clear correlation between O, Al, Fe and Si (Fig. 5). 


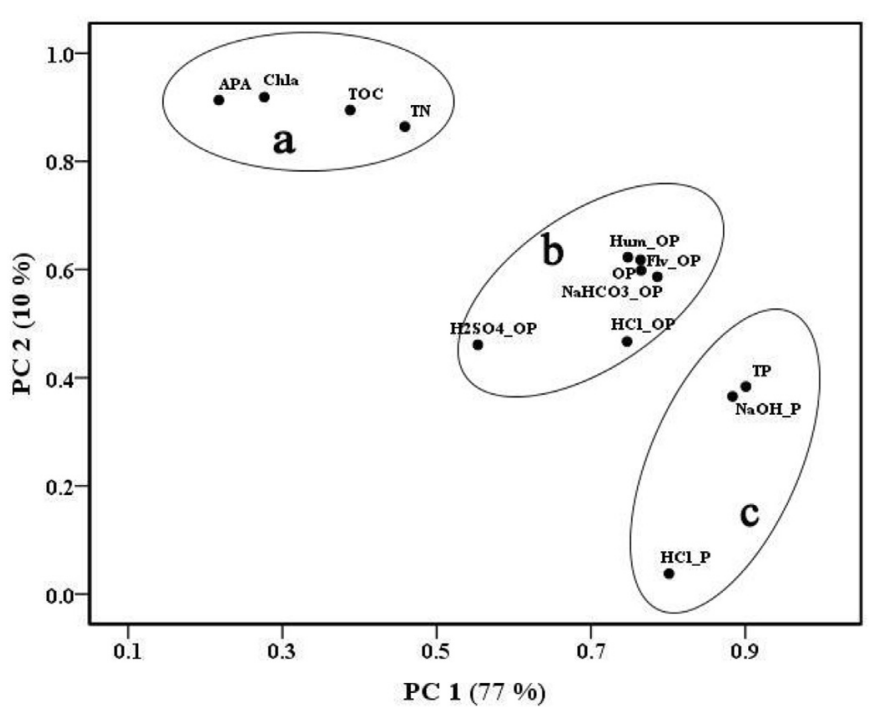

Fig. 4. The PCA results of various phosphorus fractions and environmental factors (PC1, 77\% variance; $\mathrm{PC} 2,10 \%$ variance).

Therefore, most metal-oxide compounds were hydroxyl aluminum and/or Al-O-Si oxides, and Fe-Si oxides combining with a small amount of Mg. This provided the advantage that the soluble reactive phosphorus (SRP) from the overlying water could be attached to the surface of the above generated metal-oxide compounds transferring it into the NaOH-P fraction. Thus, the concentration of $\mathrm{NaOH}-\mathrm{P}$ was generally high at the sampling sites, with relatively high salinity and ORP in the JL onshore sediments. However, the JH is a freshwater river that has relatively high concentrations of $\mathrm{NaOH}-\mathrm{P}$ but low $\mathrm{HCl}-\mathrm{P}$, which could be mainly due to the severe disturbance of the JH onshore sediment by dredging. This implies that the SRP from the overlying water was first attached to the metal oxide-generating NaOH-P but could not be rapidly converted to Ca-P during early diagenesis (Ruttenberg and Berner, 1993). Additionally, sediment dredging could also regenerate $\mathrm{P}$ from $\mathrm{HCl}-\mathrm{P}$ and $\mathrm{OP}$ due to the $\mathrm{HCl}-\mathrm{P}$ and $\mathrm{OP}$ being oxidised during the dredging process (deeper sediments overturned to surface sediments) with $\mathrm{HCl}-\mathrm{P}$ and OP fractions subsequently exposed to oxygen and sunlight slowly degrading due to photolysis and weathering (Chen et al., 2018). The regenerated P could accumulate on the freshly dredged surface sediments to generate NaOH-P (Chao et al., 2017; Yu et al., 2017). Thus, the $\mathrm{HCl}$ and $\mathrm{OP}$ contents were relatively lower, but the NaOH-P concentration higher, in the JH onshore sediments than at the other sampling sites. However, the HCl-P was the basic fraction that made up more than $80.0 \%$ of TP in offshore sediments of both rivers. Previous studies have demonstrated that there are greater proportions of $\mathrm{HCl}-\mathrm{P}$ but less $\mathrm{NaOH}-\mathrm{P}$ and $\mathrm{OP}$ in rivers with little pollution, estuaries and clean marine sediments (Ruban et al., 2001). We inferred that $\mathrm{NaOH}-\mathrm{P}$ was a potentially reactive fraction in the sediment that could be easily exchanged into and therefore, diluted by, the overlying water column. Previous reports have suggested that the salinity of seawater could induce $P$ to be released from $\mathrm{Fe} / \mathrm{Mn} / \mathrm{Al}$ (hydroxides) oxides in sediments resulting from hydroxyl or other ions exchanged from the seawater preferentially occupying binding sites of $\mathrm{Fe} / \mathrm{Mn} / \mathrm{Al}$ (hydroxides) oxides. The high salinity could also cause plasmolysis of sediment bacteria, which results in cell rupture and release of OP (Gardolinski et al., 2004). However, the $\mathrm{HCl}-\mathrm{P}$ was potentially a stable fraction in sediment that could not be easily released but could be accumulated persistently. Therefore, the $\mathrm{HCl}-\mathrm{P}$ would be the primary fraction under the less SRP and OP inputs condition. Additionally, it could be argued that the sorption and desorption of the sedimentary $\mathrm{P}$ is connected to sediment grain-size. Generally, there were more

$\mathbf{A}$
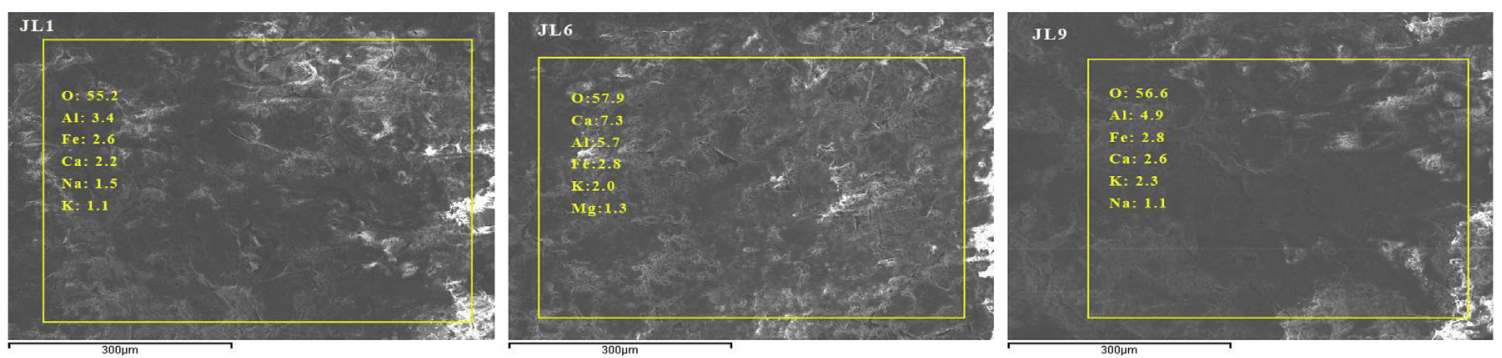

B
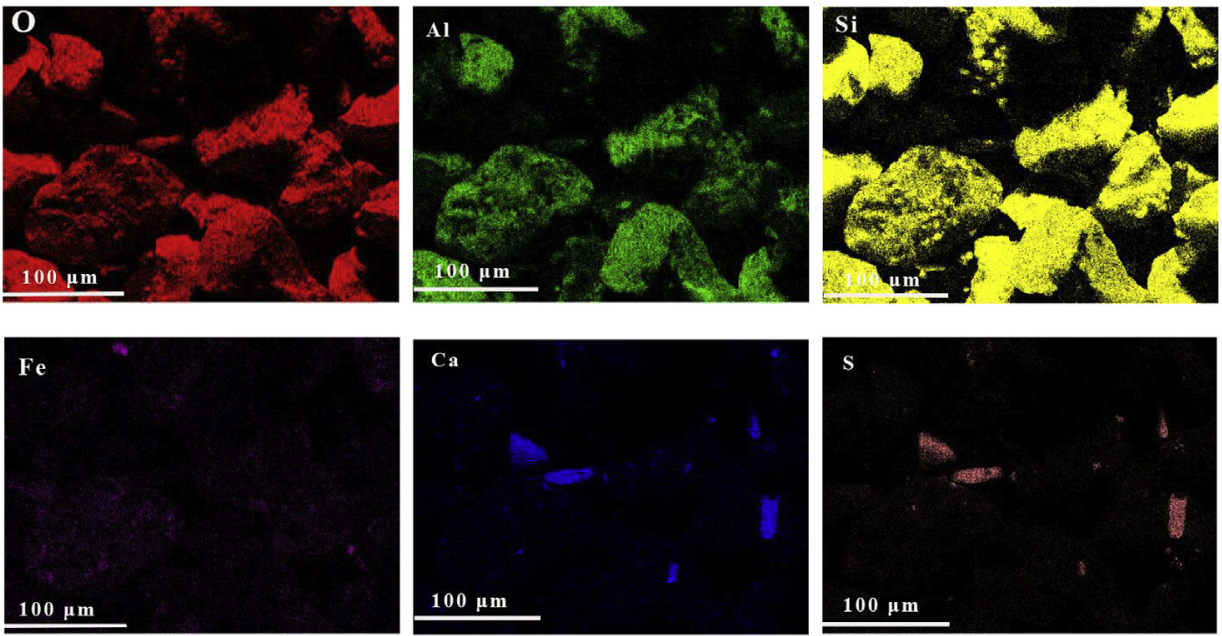

Fig. 5. SEM images with EDS the results of relative abundance of top five metals and oxygen in the JL1, JL6 and JL9 sediments (A); Elemental mapping of JL6 (B). 
coarse-grain-sized particles in JL samples than JH. Only the relative distribution of $\mathrm{NaOH}-\mathrm{P}$ had a significant negative correlation with the coarse-grain-size particle content $(r=-0.373, p<0.05)$ at all sampling sites, implying that $\mathrm{NaOH}-\mathrm{P}$ was more likely to cluster in fine particles than $\mathrm{HCl}-\mathrm{P}$ and OP.

Although the TOP concentrations in the JH onshore sediments were approximately three times higher than the JL onshore sediments, the TOP content in the offshore sediments for both rivers exhibited little difference (Fig. 2 II). This demonstrates that the ocean has a tremendous ability to dilute and distribute riverine inputs (Andresen et al., 2007). Thus, the difference in TOP content between the two rivers is easily smoothed by dilution and not represented in the offshore sediments. Additionally, the high salinity in the overlying water could result in plasmolysis of sediment organism which results in cell rupture and release of OP as shown by a greater proportion of DNA in sample JL9 compared with JL5 (Fig. 3). Therefore, both the content and potential activity of OP in the sediments with high salinity was relatively low. Furtherly, content of each of the OP fractions was significantly different in the offshore sediments of both rivers. For example, the average concentration of $\mathrm{HCl}-\mathrm{OP}$ in the $\mathrm{JL}$ offshore sediments was generally higher than that in the JH offshore sediments and the mean content of $\mathrm{NaHCO}_{3}-\mathrm{OP}$ was overall higher in the $\mathrm{JH}$ offshore sediments than that in the JL offshore sediments. It could possibly be due to the smaller average grain size in JH offshore sediments (Fig. S2) with the $\mathrm{NaHCO}_{3}-\mathrm{OP}$ more readily combining with the smaller particles sediments while $\mathrm{HCl}-\mathrm{OP}$ being more associated with larger particle sizes. Moreover, the salinity of the overlying water could significantly reduce the concentrations of Chl $a$ and APA (Games-Howell test, $\mathrm{p}<0.001$ and $\mathrm{p}<0.05$, respectively) by reducing hydrophytes and bacterial growth. Salinity could possibly therefore be an indicator for bio-availability of $P$ because hydrophytes and bacteria are two major sources of alkaline phosphatase in nature (Dai et al., 2017). At all sampling sites, the JL offshore sediments had an abnormal relative distribution of Flv-OP, which contained less moderately labile OP than $\mathrm{HCl}-\mathrm{OP}$ compared to the other sites. This possibly results from the high salt contents producing abundant hydrophytes that grow strongly in the JL. Consequently, the TOC content of the hydrophytes flowed into the JL offshore area when the current was at a minimum (Table 2), resulting in less Flv-OP in the JL offshore sediment. Additionally, alkaline phosphatase could hydrolyze sectional OP into active $\mathrm{P}(\mathrm{NaOH}-\mathrm{P})$ prior to uptake by algae or other organisms (Zhu et al., 2013b). This could also explain why the relative distribution of the active $\mathrm{NaOH}-\mathrm{P}$ fraction was generally low in the JL onshore sediments and the offshore sediments of both rivers, i.e., because salt inhibited the APA. Furthermore, the potential activity of OP was generally higher in the $\mathrm{JH}$ onshore sediment than in the other sediments, with a minimum relative distribution of non-labile OP $(56.8 \%)$ and a maximum relative distribution of moderately labile OP (33.3\%), which possibly resulted from dredging and could possibly increase the potential activity of OP (mainly moderately labile OP). The OP in deeper sediments could be overturned to the surface of the sediments after dredging. Thus, the large OP molecules could be degraded into small OP molecules under photolysis and weathering conditions. The high salinity could also possibly promote the transformation of moderately labile OP to non-labile OP.

The $\mathrm{JH}$ is a heavily polluted fresh water river with the most sedimentary TP, i.e., more than $1000 \mathrm{mg} \mathrm{kg}^{-1}$ (Table 1). Additionally, the $\mathrm{JH}$ sediments had a greater range of $\mathrm{P}$ containing compounds than the JL sediments. It should be noted that the greatest variety of P occurred at the upstream JH5 sampling site, where phosphonate was present. Additionally, a previously published study (Kittredge and Roberts, 1969) demonstrated that phosphonate generally exists in eutrophic lakes, indicating that the upper reaches of the JH were possibly at risk of eutrophication. Compared to the higher-salinity sampling site, a greater range of P-containing compounds were present at sampling sites with low salinity and only orthophosphate was present in the offshore sediments of both rivers, presumably resulting from sediment properties other than salinity. It has been reported that soils and/or sediments with a higher content of $\mathrm{HCl}-\mathrm{P}$ and low TOC usually yield a lower recovery of $\mathrm{P}$ in the EDTA-NaOH extracts, due to the relative stability of $\mathrm{HCl}-\mathrm{P}$ inhibiting extraction by EDTA-NaOH and the OP content was indeed low in sediments (Zhu et al., 2018).

\subsection{Evaluation of potential for $P$ release}

Understanding the potential release of P from sediments under high salinity and dredging conditions can provide valuable information with which to enhance our knowledge of eutrophication. Moreover, the NaOH-P fraction is mainly formed from P-bound to Fe/Al oxides and hydroxides, which are potentially active and can easily lead to $\mathrm{P}$ being released into the overlying water for bioutilization (Reitzel et al., 2006). The TP values in the JH onshore sediments were greater than $800 \mathrm{mg} \mathrm{kg}^{-1}$ (the highest TP reached $\sim 3000 \mathrm{mg} \mathrm{kg}^{-1}$ ), and the $\mathrm{NaOH}-\mathrm{P}$ content was also relatively high, which could indicate that the $\mathrm{JH}$ is significantly polluted with $\mathrm{P}$ and has a high potential for release, while the onshore sediment dredging and high APA of the JH could also possibly improve the regeneration level of $\mathrm{P}$ from $\mathrm{HCl}-\mathrm{P}$ and OP. Furthermore, the OP potential activity was generally higher in the $\mathrm{JH}$ onshore sediments than at the other sampling sites under dredging condition, which could also improve the risk level for OP release. Although the $\mathrm{HCl}-\mathrm{P}$ fraction dominated the TP under the acidic overlying water (mean $\mathrm{pH}=4$ ), most $\mathrm{HCl}-\mathrm{P}$ was $\mathrm{CaSO}_{4}-\mathrm{P}$ that could still be stable in these conditions, demonstrating that the JL was generally at a low level of $\mathrm{P}$ regeneration from HCl-P. Additionally, the relatively low $\mathrm{pH}$ and high salinity could reduce the APA and lead to organism plasmolysis (most of OP in organisms had probably already been released) resulting in $\mathrm{P}$ regeneration from $\mathrm{OP}$ being relatively low, especially in the middle and lower reaches of the JL. Generally, the level of P release from the offshore sediments of both rivers was relatively low because the proportion of the potentially active NaOH-P fraction was significantly lower than in the onshore sediments of both rivers (Games-Howell test, $\mathrm{p}<0.01$ ). Additionally, the proportion of non-labile OP in the offshore sediments of both rivers accounted for nearly $80.0 \%$ of TOP, which was significantly higher than in the $\mathrm{JL}$ and $\mathrm{JH}$ onshore sediments (Games-Howell test, $\mathrm{p}<0.05$ ). The ${ }^{31} \mathrm{P}-\mathrm{NMR}$ analysis demonstrated that Mono-P was the major OP compound in the offshore sediments of both rivers. Mono-P is relatively stable, as indicated by its 23-year half-life (Ahlgren et al., 2005; Ding et al., 2013). Therefore, the level of $P$ release from OP was low under the high ORP of the overlying water and the low APA in the offshore sediments of both rivers.

\section{Conclusions}

1) Anthropogenic input was the primary source of IP (i.e., $\mathrm{HCl}-\mathrm{P}$ and $\mathrm{NaOH}-\mathrm{P}$ ). Both indigenous biological and anthropogenic inputs were possibly significant sources of each OP fraction.

2) Sediment dredging could improve the level of $P$ release due to regenerated $\mathrm{P}$ from $\mathrm{HCl}-\mathrm{P}$ and $\mathrm{OP}$ and increase the potential activity of OP and IP (primarily moderately labile $\mathrm{OP}$ and $\mathrm{NaOH}-$ P).

3) High salinity made the OP relatively stable at a low risk of release due to inhibiting OP hydrolysis, promoting the OP release from the organism and the moderately labile OP to 
transform into non-labile OP. High salinity could also increase $\mathrm{NaOH}-\mathrm{P}$ content in acidic river sediments.

4) Seawater could induce removal of the $\mathrm{NaOH}-\mathrm{P}$ and $\mathrm{OP}$ from offshore sediment resulting in the releasing level of remaining $P$ at a low level.

\section{Acknowledgments}

This study was supported by the National Natural Science Foundation of China (Grant No.: 41373100). Additional support was provided by the Key Project of Research and Development Plan of Yantai (Grant No.: 2018ZHGY083) and the CAS Key Technology Talent Program. Many thanks go to Miss Shanshan Yang for her detailed helping us conduct the one-way ANOVA and PCA of the data analysis. Specially thank Dr. Xiuli Yin from the Analytical Center of Yantai Institute of Coastal Zone Research for her helping us in our ${ }^{31} \mathrm{P}-\mathrm{NMR}$ determination and analysis, which greatly improved the rigor of this ${ }^{31} \mathrm{P}-\mathrm{NMR}$ work. Thanks to Dr. Andrew Revill for comments on a draft of this manuscript.

\section{Appendix A. Supplementary data}

Supplementary data to this article can be found online at https://doi.org/10.1016/j.chemosphere.2018.10.015.

\section{References}

Abdi, D., Cade-Menun, B.J., Ziadi, N., Parent, L.-E., 2015. Compositional statistical analysis of soil P-31-NMR forms. Geoderma 257, 40-47.

Ahlgren, J., Tranvik, L., Gogoll, A., Waldebäck, M., Markides, K., Rydin, E., 2005 Sediment depth attenuation of biogenic phosphorus compounds measured by 31P NMR. Environ. Sci. Technol. 39, 867-872.

Andresen, J.A., Muir, D., Ueno, D., Darling, C., Theobald, N., Bester, K., 2007. Emerging pollutants in the north sea in comparison to Lake Ontario, Canada, data. Environ. Toxicol. Chem. 26, 1081-1089.

Arnon, D.I., 1949. Copper enzymes in isolated chloroplasts-polyphenoloxidase in beta-vulgaris. Plant Physiol. 24, 1-15.

Aspila, K.I., Agemian, H., Chau, A.S.Y., 1976. Semi-automated method for determination of inorganic, organic and total phosphate in sediments. Analyst 101 187-197.

Bertrand, O., Mansuy-Huault, L., Montargès-Pelletier, E., Losson, B., Argant, J. Ruffaldi, P., Etienne, D., Garnier, E., Dezileau, L., Faure, P., Michels, R., 2012. Molecular evidence for recent land use change from a swampy environment to a pond (Lorraine, France). Org. Geochem. 50, 1-10.

Cade-Menun, B.J., 2005. Characterizing phosphorus in environmental and agricultural samples by P-31 nuclear magnetic resonance spectroscopy. Talanta 66 , 359-371.

Cade-Menun, B.J., 2015. Improved peak identification in P-31-NMR spectra of environmental samples with a standardized method and peak library. Geoderma 257, 102-114.

Cade-Menun, B.J., Preston, C.M., 1996. A comparison of soil extraction procedures for P-31 NMR spectroscopy. Soil Sci. 161, 770-785.

Cade-Menun, B., Liu, C.W., 2014. Solution phosphorus-31 nuclear magnetic resonance spectroscopy of soils from 2005 to 2013: a review of sample preparation and experimental parameters. Soil Sci. Soc. Am. J. 78, 19-37.

Chao, J.Y. Zhang, Y.M., Kong, M., Zhuang, W., Wang, L.M., Shao, K. O Gao, G., 2017 Long-term moderate wind induced sediment resuspension meeting phosphorus demand of phytoplankton in the large shallow eutrophic Lake Taihu. Plos One 12,1-15.

Chen, D., Zheng, A., Chen, M., 2010. Study of colloidal phosphorus variation in estuary with salinity. Acta Oceanol. Sin. 29, 17-25.

Chen, M.S., Cui, J.Z., Lin, J., Ding, S.M., Gong, M.D., Ren, M.Y., Tsang, D.C.W., 2018 Successful control of internal phosphorus loading after sediment dredging for 6 years: a field assessment using high-resolution sampling techniques. Sci. Total Environ. 616, 927-936.

Dai, Y., Wu, J. Ma, X. Zhong, F. Cui, N.. Cheng, S. 2017. Increasing phytoplanktonavailable phosphorus and inhibition of macrophyte on phytoplankton bloom. Sci. Total Environ. 579, 871-880

Ding, S., Xu, D., Bai, X., Yao, S., Fan, C., Zhang, C., 2013. Speciation of organic phosphorus in a sediment profile of Lake Taibu II. Molecular species and their depth attenuation. J. Environ. Sci. 25, 925-932.

Feng, W., Wu, F., He, Z., Song, F., Zhu, Y., Giesy, J.P., Wang, Y., Qin, N., Zhang, C. Chen, H., Sun, F., 2018. Simulated bioavailability of phosphorus from aquatic macrophytes and phytoplankton by aqueous suspension and incubation with alkaline phosphatase. Sci. Total Environ. 616, 1431-1439.

Feng, W., Zhu, Y., Wu, F., Meng, W., Giesy, J.P., He, Z., Song, L., Fan, M., 2016.
Characterization of phosphorus forms in lake macrophytes and algae by solution 31P nuclear magnetic resonance spectroscopy. Environ. Sci. Pollut. Control Ser. $23,7288-7297$.

Gardolinski, P., Worsfold, P.J., McKelvie, I.D., 2004. Seawater induced release and transformation of organic and inorganic phosphorus from river sediments. Water Res. 38, 688-692.

Hadas, O., Pinkas, R., 1997. Arylsulfatase and alkaline phosphatase (apase) activity in sediments of lake kinneret, Israel. Water Air Soil Pollut. 99, 671-679.

Huang, Q.H., Wang, Z.J., Wang, C.X., Wang, S.R., Jin, X.C., 2005. Phosphorus release in response to $\mathrm{pH}$ variation in the lake sediments with different ratios of ironbound P to calcium-bound P. Chem. Speciat. Bioavailab. 17, 55-61.

Ivanoff, D.B., Reddy, K.R., Robinson, S., 1998. Chemical fractionation of organic phosphorus in selected histosols. Soil Sci. 163, 36-45.

Jordan, T.E., Cornwell, J.C., Boynton, W.R., Anderson, J.T., 2008. Changes in phosphorus biogeochemistry along an estuarine salinity gradient: the iron conveyer belt. Limnol. Oceanogr. 53, 172-184.

Kao, S.J., Lin, F.J., Liu, K.K., 2003. Organic carbon and nitrogen contents and their isotopic compositions in surficial sediments from the East China Sea shelf and the southern Okinawa Trough. Deep-Sea Res. Part II Top. Stud. Oceanogr. 50, $1203-1217$.

Kittredge, J.S., Roberts, E., 1969. A carbon-phosphorus bond in nature. Science 164, $37-42$.

Labry, C., Delmas, D., Youenou, A., Quere, J., Leynaert, A., Fraisse, S., Raimonet, M. Ragueneau, O., 2016. High alkaline phosphatase activity in phosphate replete waters: the case of two macrotidal estuaries. Limnol. Oceanogr. 61, 1513-1529.

Li, Z., Sheng, Y., Yang, J., Burton, E.D., 2016. Phosphorus release from coastal sediments: impacts of the oxidation-reduction potential and sulfide. Mar. Pollut. Bull. 113, 176-181.

Matsue, N., Wada, K., 1989. Source minerals and formation of partially interlayered vermiculites in dystrochrepts derived from tertiary sediments. J. Soil Sci. 40, $1-7$.

McDowell, R.W., Stewart, I., Cade-Menun, B.J., 2006. An examination of spin-lattice relaxation times for analysis of soil and manure extracts by liquid state phosphorus-31 nuclear magnetic resonance spectroscopy. J. Environ. Qual. 35, 293-302.

Meng, J., Yu, Z., Yao, Q., Bianchi, T.S., Paytan, A., Zhao, B., Pan, H., Yao, P., 2015. Distribution, mixing behavior, and transformation of dissolved inorganic phosphorus and suspended particulate phosphorus along a salinity gradient in the Changjiang Estuary. Mar. Chem. 168, 124-134.

Mi, Y., Chen, D., Wang, S., 2018. Utilization of phosphogypsum for the preparation of -calcium sulfate hemihydrate in chloride-free solution under atmospheric pressure. J. Chem. Technol. Biotechnol. 93, 2371-2379.

Murphy, J., Riley, J.P., 1962. A modified single solution method for determination of phosphate in natural waters. Anal. Chim. Acta 26 (C), 678-681.

Nasr, S.M., Okbah, M.A., El-Anany, W.I., Soliman, N.F., 2018. Chemical fractionation of aluminium in the sediments of El-Burullus lagoon of nile delta, Egypt. Geochem. Int. 56, 182-188.

Owens, P.N., Walling, D.E., 2002. The phosphorus content of fluvial sediment in rural and industrialized river basins. Water Res. 36, 685-701.

Reitzel, K., Ahlgren, J., Gogoll, A., Rydin, E., 2006. Effects of aluminum treatment on phosphorus, carbon, and nitrogen distribution in lake sediment: a P-31 NMR study. Water Res. 40, 647-654.

Ruban, V., Lopez-Sanchez, J.F., Pardo, P., Rauret, G., Muntau, H., Quevauviller, P., 2001. Harmonized protocol and certified reference material for the determination of extractable contents of phosphorus in freshwater sediments - a synthesis of recent works. Fresen. J. Anal. Chem. 370, 224-228.

Ruttenberg, K.C., Berner, R.A., 1993. Authigenic apatite formation and burial in sediments from non-upwelling, continental-margin environments. Geochem. Cosmochim. Acta 57, 991-1007.

Schindler, D.W., 1977. Evolution of phosphorus limitation in lakes. Science 195, $260-262$.

Shan, B., Li, J., Zhang, W., Di, Z., Jin, X., 2016. Characteristics of phosphorus components in the sediments of main rivers into the Bohai Sea. Ecol. Eng. 97, $426-433$.

Sondergaard, M., Jensen, J.P., Jeppesen, E., 2003. Role of sediment and internal loading of phosphorus in shallow lakes. Hydrobiologia 506, 135-145.

Story, S., Bowen, B.B., Benison, K.C., Schulze, D.G., 2010. Authigenic phyllosilicates in modern acid saline lake sediments and implications for Mars. J. Geophys. Res.Planets 115.

Turner, B.L., Cade-Menun, B.J., Condron, L.M., Newman, S., 2005. Extraction of soil organic phosphorus. Talanta 66, 294-306.

Vestergren, J., Vincent, A.G., Jansson, M., Persson, P., Istedt, U., Groebner, G., Giesler, R., Schleucher, J., 2012. High-resolution characterization of organic phosphorus in soil extracts using 2D H-1-P-31 NMR correlation spectroscopy. Environ. Sci. Technol. 46, 3950-3956.

Wang, L. Xia, J., Yu, J., Yang, L., Zhan, C. Oiao, Y., Lu, H., 2017a. Spatial variation, pollution assessment and source identification of major nutrients in surface sediments of Nansi Lake, China. Water 9, 444.

Wang, Q., Li, Y., Ouyang, Y., 2011. Phosphorus fractionation and distribution in sediments from wetlands and canals of a water conservation area in the Florida Everglades. Water Resour. Res. 47, 1-11.

Wang, S., Jin, X., Zhao, H., Wu, F., 2006. Phosphorus fractions and its release in the sediments from the shallow lakes in the middle and lower reaches of Yangtze River area in China. Colloid. Surface. Physicochem. Eng. Aspect. 273, 109-116.

Wang, Y., Wu, X., Zhang, Q., Hou, M., Zhao, H., Xie, Q., Du, J., Chen, J., 2017b. 
Organophosphate esters in sediment cores from coastal Laizhou bay of the Bohai Sea, China. Sci. Total Environ. 607, 103-108.

Yang, B., Liu, S.M., Wu, Y., Zhang, J., 2016. Phosphorus speciation and availability in sediments off the eastern coast of Hainan Island, South China Sea. Continent. Shelf Res. 118, 111-127.

Yang, M., Zhang, Y., Qi, R., Uesugi, K., Myoga, H., 2001. Improved O-3/H2O2 oxidation process for wastewater reclamation. Water Sci. Technol. 43, 311-318.

Yu, J., Ding, S., Zhong, J., Fan, C., Chen, Q., Yin, H., Zhang, L., Zhang, Y., 2017. Evaluation of simulated dredging to control internal phosphorus release from sediments: focused on phosphorus transfer and resupply across the sedimentwater interface. Sci. Total Environ. 592, 662-673.

Yu, J., Fan, C., Zhong, J., Zhang, Y., Wang, C., Zhang, L., 2016. Evaluation of in situ simulated dredging to reduce internal nitrogen flux across the sediment-water interface in Lake Taihu, China. Environ. Pollut. 214, 866-877.

Zhao, G., Sheng, Y., Wang, J., Li, Z., Yang, J., 2018. Optimized digestion methods: organic phosphorus sequential extraction, total phosphorus, and nitrogen simultaneous determination in sediments. J. Soils Sediments 18, 2072-2080.
Zhong, J., Liu, G., Fan, C., Li, B., Zhang, L., Ding, S., 2009. Environmental effect of sediment dredging in lake: II. the role of sediment dredging in reducing internal nitrogen release. Scientia Limnologica Sinica 21, 335-344.

Zhu, M., Zhu, G., Li, W., Zhang, Y., Zhao, L., Gu, Z., 2013a. Estimation of the algalavailable phosphorus pool in sediments of a large, shallow eutrophic lake (Taihu, China) using profiled SMT fractional analysis. Environ. Pollut. 173, 216-223.

Zhou, Q.X., Gibson, C.E., Zhu, Y.M., 2001. Evaluation of phosphorus bioavailability in sediments of three contrasting lakes in China and the UK. Chemosphere 42, $221-225$.

Zhu, Y., Feng, W., Liu, S., He, Z., Zhao, X., Liu, Y., Guo, J., Giesy, J.P., Wu, F., 2018 Bioavailability and preservation of organic phosphorus in lake sediments: insights from enzymatic hydrolysis and 31P nuclear magnetic resonance. Chemosphere. https://doi.org/10.1016/j.chemosphere.2018.07.134.

Zhu, Y., Wu, F., He, Z., Guo, J., Qu, X., Xie, F., Giesy, J.P., Liao, H., Guo, F., 2013b. Characterization of organic phosphorus in lake sediments by sequential fractionation and enzymatic hydrolysis. Environ. Sci. Technol. 47, 7679-7687. 